\title{
ANALISIS BEBAN KERJA PADA AREA TEMPAT PENIMBUNAN KAYU(TPK) KPH MALANG
}

\author{
Darianto $^{1}$, Tatag Muttaqin ${ }^{2}$, Galit Gatut Prakosa ${ }^{3}$ \\ 1,2,3 Jurusan Kehutanan, Fakultas Pertanian-Peternakan, Universitas Muhammadiyah \\ Malang. Jl. Raya Tlogomas No 246, Tlogomas, Malang Jawa Timur 65144 \\ *E-mail: odarianto@gmail.com
}

\begin{abstract}
ABSTRAK
Analisis Beban Kerja Pada Area Tempat Penimbunan Kayu (TPK) KPH Malang. Beban kerja merupakan suatu tuntutan pekerjaan yang harus diselesaikan oleh seorang pegawai dalam waktu tertentu, setiap pegawai memiliki beban kerja masing masing tergantung penempatan dan juga posisi pekerja. Tujuan dari penelitian ini yaitu untuk mengetahui beban kerja di areal TPK saat pemanenan dan tidak ada pemanenan kemudian menganaisis beban kerja.Penelitian ini dilakukan di TPK Rejosari kecamatan Pagak, TPKH Dengkol kecamatan Jabung dan TPK karangan kecamatan Karangploso kabupaten Malang. Pengambilan data dilakukan sebanyak 5 kali saat pemanenan untuk mengetahui rata-rata beban kerja dan 1 kali saat tidak ada kegiatan pemanenan. Pengambilan data dilakuakan mengguanakn metode perhitungan beban kerja menurut kementrian ketenagakerjaan tahun 2016. Rata-rata pemanenan di TPK Rejosari sebesar 23714,2 detik. Rata-rata beban kerja saat pemanenan di TPKH Dengkol yaitu sebesar 82963,2 detik. Perbedaan beban kerja saat pemanenan sangat tinggi antara TPK Rejosari dan TPKH Dengkol dipengaruhi oleh faktor internal dan faktor external seperti, faktor internal yang mempengaruhi yaitu penempatan pegawai yang tidak sesuai di TPKH Dengkol sehingga membuat penyelesaian pekerjaan lama. Faktor eksternal yang mempengaruhi antara lain kecepatan internet yang kurang memadai di TPKH Dengkol sehingga membuat pekerjaan upload data kayu lambat, serta jumlah pekerja lepas yang berbeda membuat kegiatan penaikan kayu dan pengkaplingan kayu lama. Beban kerja saat tidak ada pemanena disetiap TPK memiliki nilai yang sama yaitu sebesar 100800 detik. Persamaan beban kerja tersebut terjadi karena kegiatan yang dilakukan pekerja sama dan waktu kerja yang sama.
\end{abstract}

Kata kunci : Analisis Beban Kerja, TPK Rejosari, TPKH Dengkol, TPK karangan.

\begin{abstract}
Work Load Analysis In The Log Yard Area (TPK) KPH Malang. Workload is a work demand that must be completed by an employee within a certain time, each employee has their own workload depending on the placement and also the position of the worker. This research was conducted at TPK Rejosari, Pagak subdistrict, TPKH Dengkol, Jabung sub-district and TPK composed of Karangploso sub-district, Malang district. Data were collected 5 times during harvesting to determine the average workload and 1(one) time when there was no harvesting. The aim of this study was to determine the workload in the TPK area when harvesting and there was no harvesting and to analyze the workload. Data collection was carried out using the workload calculation method according to the Ministry of Manpower in 2016. The average harvest at Rejosari TPK is 23714.2 seconds. The average workload during harvesting at TPKH Dengkol is equal to 82963.2 seconds. The difference in workload during harvesting is very high between TPK Rejosari and TPKH Dengkol influenced by internal factors and external factors such as internal factors, Internal factors that affect the placement of inappropriate employees in TPKH Dengkol. Thus making the completion of the work is long. External factors, such as inadequate internet speed at TPKH Dengkol, So that makes the job of uploading the data of the wood slow, as well as the number of freelancers is different making the activities of raising logs and timber milling take longer The workload when there are no harvesting in each TPK has the same value, which is 100.800 seconds. The workload equation occurs because of the activities carried out by the same workers and the same working time.
\end{abstract}

Key words : Workload Analisis, TPK Rejosari, TPKH Dengkol, TPK karangan. 


\section{PENDAHULUAN}

Sumber daya manusia (SDM) merupakan salah satu penunjang dari majunya suatu organisasi maupun perusahaan. Menurut (Qustolani 2017) karyawan adalah penggerak utama dalam suatu proses kegiatan serta menentukan kelancaran aktivitas di dalam perusahaan. SDM merupakan faktor terpenting dan sentral dalam rangka pencapaian tujuan suatu perusahaan maupun organisasi, dikarenakan dengan adanya skil para pekerja sehingga mampu mengerakkan suatu perusahaan dengan baik dan benar. Kebutuhan akan sumber daya manusia lambat laun mulai menigkat seiring dengan berkembangnya zaman. Kebutuhan ini harus di imbangi dengan tersedianya sumberdaya manusia yang kompeten. Menurut pendapat (Aisyah and Utami 2017) "Karyawan yang berkualitas serta profesional harus memiliki komitmen terhadap perusahaannya. Karyawan berjanji pada dirinya sendiri untuk bisa memajukan perusahaan agar tercapai sebuah tujuan bersama dengan kinerja yang sebaik mungkin dalam kondisi persaingan global dewasa ini, karena komitmen juga merupakan keterikatan individu pada suatu perusahaan". Upaya dalam merencanakan kebutuhan pegawai mengadakan, menyeleksi serta menempatkan pegawai pada posisi yang tepat telah menjadi perhatian penting dari suatu perusahaan. Perum Perhutani merupakan badan usaha milik negara (BUMN) yang memiliki tujuan yaitu melayani penjualan barang hasil hutan. Perhutani menjual kayu melalui beberapa TPK yang ada disetiap daerah.

Indonesia menjadi negara penghasil kayu utama dunia dalam bentuk kayu lapis, kayu gergajian, kayu pertukangan, furnitur, hingga ke produk bubur kertas (Arif 2016). KPH Malang merupakan divisi regional Perhutani Jawa timur yang memiliki wilayah di Kabupaten Malang Kabupaten Kediri dan Kota Batu. Hasil kayu dari hutan produksi tidak langsung di pasarkan kemasyarakat melainkan harus melalui proses yang dilakukan ditempat penimbunan kayu (TPK). Tempat Penimbunan Kayu Hutan selanjutnya disebut TPK Hutan adalah tempat milik pemegang izin yang berfungsi menimbun kayu bulat dari beberapa TPn, yang lokasinya berada dalam areal pemegang izin (Kementerian Lingkungan Hidup Dan Kehutanan, 2015). TPK yang ada di Malang berjumlah empat yaitu TPK Sumantoro yang terletak di kecamatan Pujon, TPK karangan yang terletak di kecamatan Karangploso, TPK rejosari yang terletak di Pagak dan TPK Druju yang terletak di kecamatan Sumber Manjing.

Setiap TPK memiliki pekerja yang telah masuk kedalam divisi masingmasing seperti mandor penerima, penguji, operator dan tata usaha, mandor kapling kepala TPK dan pekerja lepas. Pekerja dituntut untuk melakukan kegiatan masing-masing dengan tepat. Menurut (Zulfiqar et al. 2017)" Apabila kondisi kerja yang demikian cukup buruk, maka akan terjadi. Kelelahan dan stres yang disebabkan kondisi fisik. Menurut (Susanti 2016) "Istilah kelelahan biasanya menunjukkan kondisi yang berbeda-beda dari setiap individu, tetapi semuanya berakibat kepada kehilangan efisiensi dan penurunan kapasitas kerja serta ketahanan tubuh. Berdasarkan uraian tersebut perlu dilakukan analisis beban kerja mengingat beban kerja merupakan sejumlah kegiatan yang membutuhkan kemampuan yang harus diselesaikan dalam jangka waktu tertentu.

\section{METODA PENELITIAN}




\subsection{Tempat dan Waktu}

Penelitian ini dilakukan di TPKH Dengkol, TPK Rejosari, TPK Karangan dan dilaksanakan pada bulan September 2019 selama 60 hari. Subjek data yang diamati yaitu pekerja yang ada di TPK.

\subsection{Pengumpulan Data}

Pengumpulan data dilakukan dua kali yaitu pada saat ada pemanenan kayu dan tidak ada pemanenan kayu. Pengumpulan data pada waktu pemanenan kayu di lakukan pada saat pekerja melakukan tugasnya masing-masing, sedangkan pada saat tidak pemanenan kayu dilakukan karena bisa melihat kegiatan tidak produktif dari pegawai. Teknik pengumpulan dilakukan Observasi (observation) yaitu kegiatan mengamati secara langsung dengan mencatat gejala-gejala yang ditemukan dilapangan. Perhitungan beban kerja dilakukan dengan pendekatan tugas pertugas jabatan sesuai dengan Keputusan Menteri Ketenagakerjaan Nomor 128 Tahun 2016 Tentang Pedoman Analisis Beban Kerja Di Kementrian Aparatur Negara yaitu sebagai berikut :

1. Menetapkan waktu kerja

Waktu kerja yang dimaksud adalah waktu kerja efektif yang dilakukan oleh pegawai untuk kegiatan pokok.

a. Jam kerja efektif dapat diketahui dengan menghitung jam kerja dalam sehari dikurangi oleh waktu allowance (waktu istirahat sholat dan makan).

2. Menyusun waktu penyelesaian tugas

a. Waktu penyelesaian tugas merupakan waktu yang total dalam menyelesaikan tugas. Hasil waktu penyelesaian tugas didapat dari perkalian antara beban kerja dan standart kemapuan rata-rata. Berikut merupakan tabel perhitngan waktu penyelesaian tugas (Keputusan Mentri Ketenagakerjaan 2016).

b. Mengulangi pengambilan data sampai lima kali untuk mendapatkan rata-rata beban kerja di TPK. Pengumpulan data waktu saat pemanenan dilaksanakan secara berulang (repetitive) dan seragam pada setiap unsur pekerjaan yang homogen dengan teratur sehingga dapat dihitung waktu bakunya sebagai waktu yang digunakan berdasarkan standar kemampuan rata-rata karyawan dalam melaksanakan setiap elemen pekerjaan (Subagja 2015).

\section{HASIL PENELITIAN DAN PEMBAHASAN}

\subsection{Perhitungan Jam Kerja Efektif} Jumlah jam kerja efektif perhari TPK yaitu 8 jam, jam kerja efektif merupakan waktu yang harus diisi dengan tindakan kerja untuk menghasilkan suatu produk maupun jasa (Kementrian Ketenagakerjaan, 2016), setiap TPK berbeda jam masuk seperti TPK Rejosari yang masuk mulai jam 7 pagi, TPKH Dengkol yang masuk mulai jam 8 pagi. Perbedaan jam keja tersebut dikarenakan menyesuaikan tempat kerja pegawai TPK dan tempat tinggal. Jumlah jam kerjaefektif yang ada di TPK yaitu 6,5 jam atau 390 menit jumlah tersebut diperoleh dari jumlah jam kerja efektif perhari dikurangi jumlah waktu allowance. Waktu allowance merupakan waktu yang digunakan oleh pekerja untuk shalat makan dan beristirahat. Total 
waktu allowance yang digunakan yaitu 1,5jam atau 90 menit. Satu minggu kerja para pegawai bekerja dalam 6 hari dan satu hari libur. Jumlah jam kerja efektif perminggu yaitu 39 jam kerja atau 2340 menit.

Tabel 1. Perhitungan Jam Kerja Efektif

\begin{tabular}{lcc}
\hline Perhitungan jam kerja perhari & Menit & Jam \\
\hline Jumlah jam kerja sehari & 480 & 8 \\
\hline Waktu allowance kerja perhari & 90 & 1,5 \\
\hline Jumlah jam kerja efektif perhari & & 6,5 \\
\hline
\end{tabular}

\subsection{Beban Kerja TPK Rejosari Saat Pemanenan}

Saat pemanenan tahun 2019 kayu yang diolah di TPK rejosari yaitu kayu pinus dengan diameter dibawah $30 \mathrm{~cm}$. Kayu tersebut berasal dari hutan Pinus BKPH Kepanjen.

\section{Rata-rata Beban Kerja Saat Pemanenan TPK Rejosari}

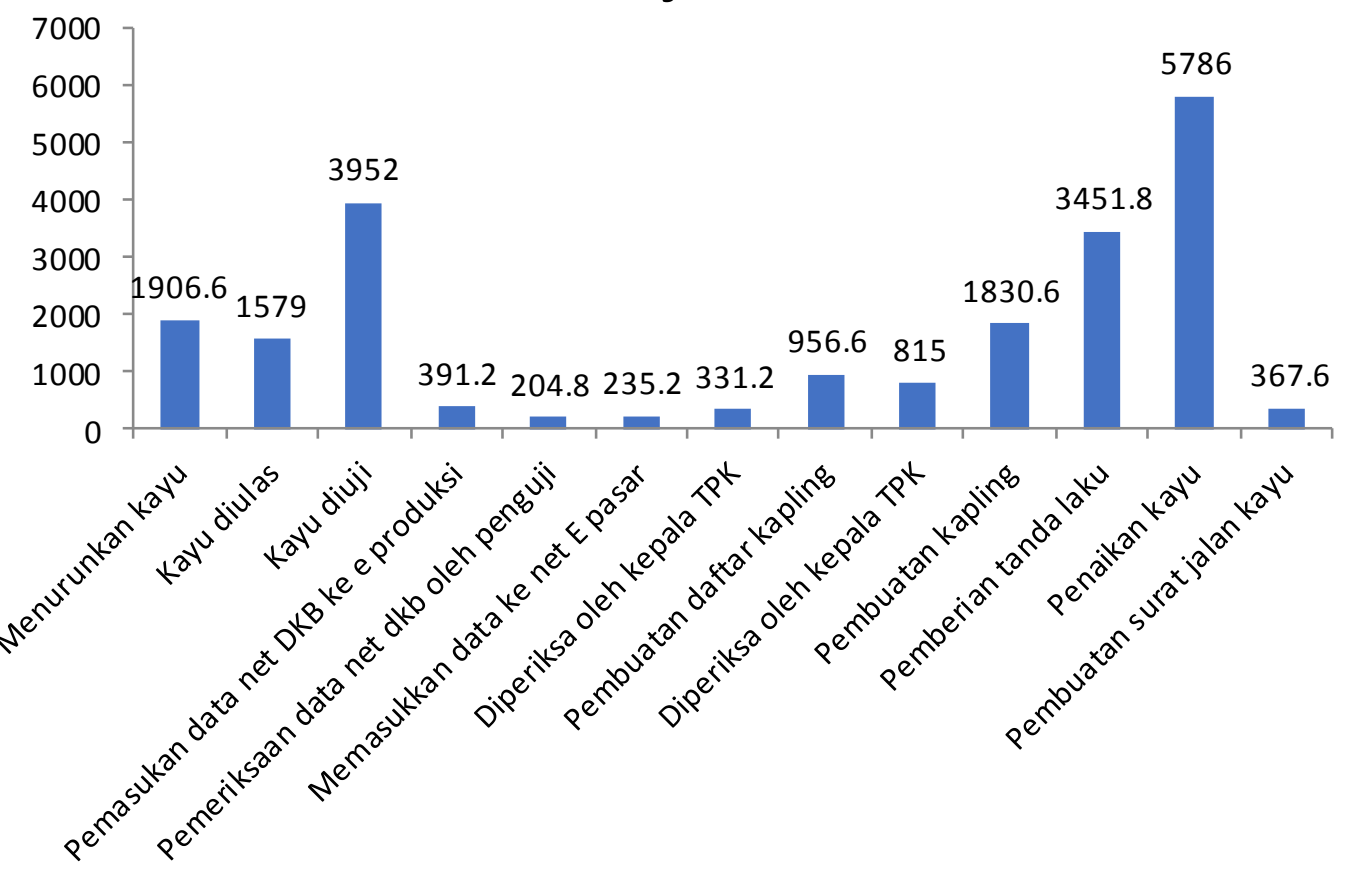

Grafik 1. Rata-rata Perhitungan Beban Kerja Saat Pemanenan TPK Rejosari

Total rata -rata beban kerja saat pemanenan di TPK rejosari yaitu 23714,2 detik. Rata-rata beban kerja tertinggi yang berada di TPK rejosari yaitu saat 
penaikan kayu hal ini dikarenakan jumlah kayu yang diangkat oleh pekerja terlalu banyak dan pekerja masih minim hal ini senada dengan pendapat juniarti dalam jurnalnya "beban kerja dapat meningkatkan kelelahan pekerja dalam menyelasaikan pekerjaannya yang tidak sesuai dengan kemampuan fisik dan mentalnya dapat menyebabkan berkurangnya kapasitas kerja dan ketahanan tubuh sehingga akan menurunkan kinerja" (Juniati 2018). Rata-rata Beban kerja terendah di TPK ini terjadi saat pemeriksaan data oleh penguji TPK melakukan peng dan menguasai tugas tugasnya hal ini senada dengan pendapat (Kusuma 2018) dalam jurnalnya yang berisi "Tuntutan tugas seimbang dengan kemampuan pekerja, maka akan tercapai kondisi kerja yang nyaman, aman, dan produktif".

\subsection{Beban Kerja TPKH Dengkol saat pemanenan}

\section{Rata-rata Beban Kerja Saat Pemanenan TPKH Dengkol}

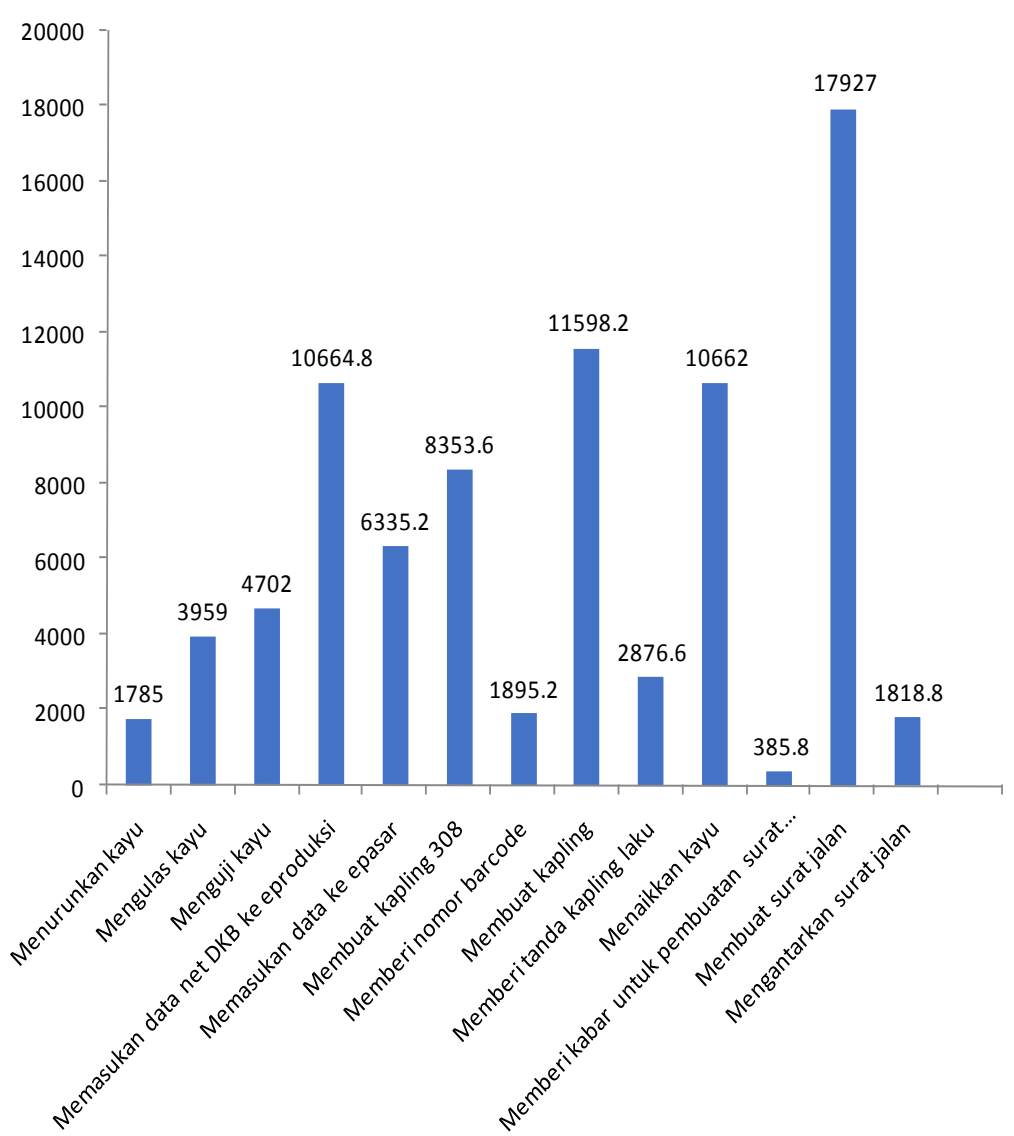

Grafik 2. Perhitungan Beban Kerja Saat Pemanenan TPKH Dengkol 
Jumlah rata -rata Beban kerja di TPKH Dengkol 82963,2 detik. Beban kerja tertinggi di TPKH Dengkol yaitu saat membuat surat jalan masalah yang ditemui yaitu pemasukan data kayu yang rumit, sering terjadinya kekeliruan data dan hanya satu operator yang mengusasi bidangnya sedangkan bagian operator lain tidak menguasai sehingga pekerjaan yang seharusnya dilakukan oleh dua orang hanya dijalankan oleh satu orang. Hal ini senada dengan pendapat (Hardono et al. 2019) "Kebutuhan pegawai yang berkompeten sesuai dengan posisi jabatannya yang belum mencukupi menimbulkan konsekuensi sikap kurang bertanggung jawab terhadap pekerjaannya,. Faktor ketidak sesuaian penempatan posisi pegawai tersebut dengan beban kerja yang ada sehingga motivasi kerja menurun".

Rata-rata Beban kerja terendah yang ada di TPKH Dengkol yaitu saat pekerja menurunkan kayunya dari hutan, hal ini dikarenakan menguasai pekerjaan yang didapat hal ini sesuai dengan pendapat (Rocky and Nurisani 2018) Baik atau kurangnya hasil kerja atau kinerja seseorang dipengaruhi oleh beberapa faktor, diantaranya: keterampilan, persepsi, peran, sikap, kepribadian, beban kerja, motivasi kerja, kepuasan kerja struktur organisasi desain pekerjaan, pengembangan karier, kepemimpinan, serta sistem penghargaan (reward sistem).

\subsection{Perbandingan Beban Kerja Saat Pemanenan}

Nilai beban kerja antara TPK Rejosari dengan TPKH dengkol cukup jauh hal ini dikarenakan banyak faktor seperti faktor teknis, penempatan pegawai dan jumlah pekerja.

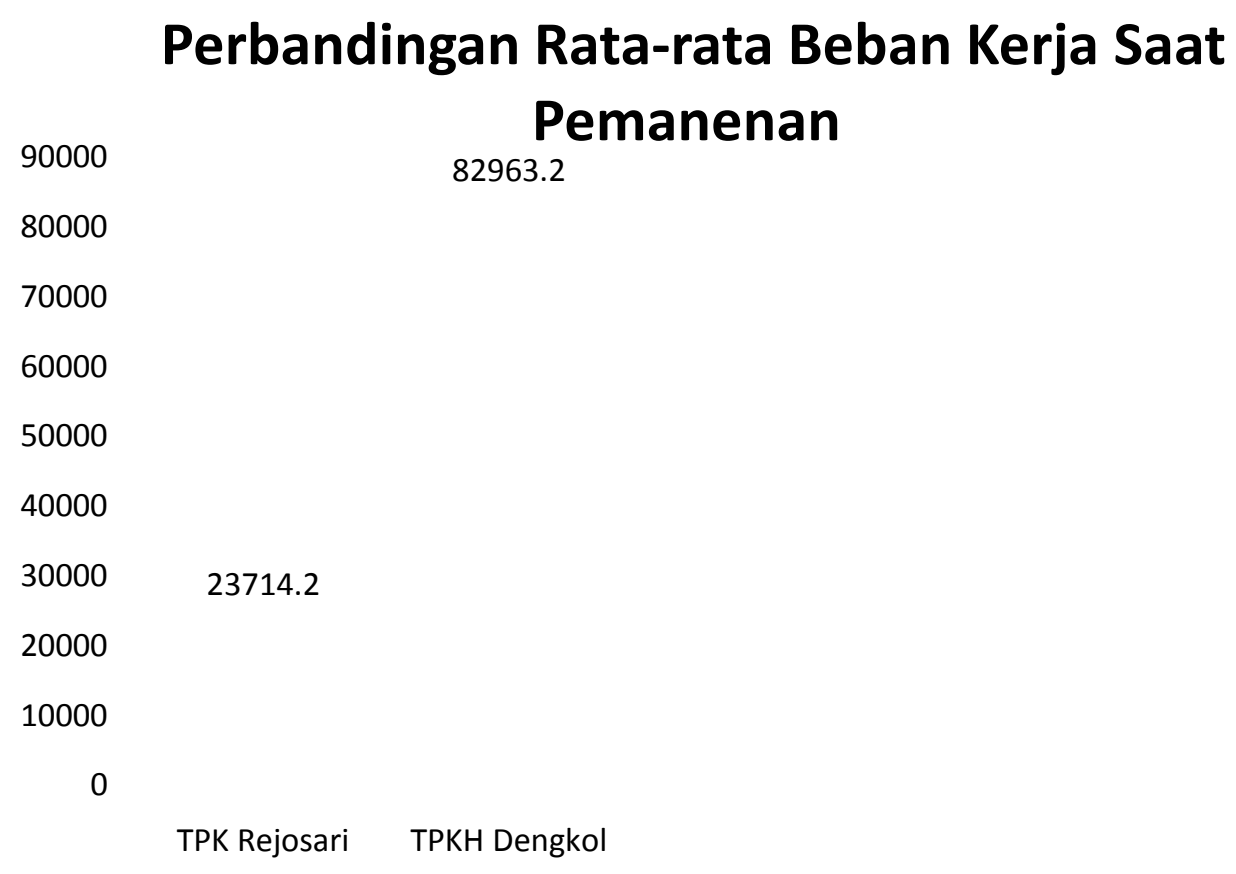

Grafik 3. Perbandingan Beban Kerja TPK Rejosari dan TPKH Dengkol 
Faktor yang mempengaruhi beban kerja antara dua TPK ini ada bermacammacam mulai dari faktor internal dan eksternal:

\section{Faktor internal}

Penempatan pegawai di TPK karangan yang kurang tepat. Jumlah operator di TPKH dengkol dan TPK Rejosari masing-masing berjumlah 2 orang, yang membedakan yaitu kemapuan pekerja dalam menyelesaikan tugas, menurut (Octavia et al. 2017) "penempatan orangorang yang tepat pada tempat yang tepat dan penempatan orang yang tepat untuk jabatan yang tepat" atau "the right man in the right place and the right man behind the right job".

\section{Faktor eksternal}

- Jumlah pekerja lepas yang berbeda. Pegawai lepas yang berada di TPK Rejosari tujuh orang sedangkan di TPKH Dengkol berjumlah 4 orang, hal ini menyebabkan beba kerja di TPKH Dengkol tinggi. Hal ini senada dengan pendapat (Setiawan and Wulandari 2016) dalam jurnalnya "Jumlah SDM tersedia tidak sebanding dengan jumlah tugas yang berlebihan membuat, yang berakibat pada tingginya beban kerja pada unit tersebut".

- Kecepatan jaringan internet yang ada dikedua TPK Berbeda. Jaringan internet di TPK Rejosari cukup untuk kegiatan di TPK berbeda dengan kecepatan jaringan internet di TPKH dengkol dan karangan yang lamban sehingga dalam hal mengerjakan tugas dengan bantuan internet cukup lama. Hal ini senada dengan pendapat (Balbeid 2017) dalam jurnalnya "Karyawan yang merasa beban kerjanya tinggi ditimbulkan adanya tugas (task) yang dilakukan bersifat fisik seperti beban kerja, tempat kerja, alat dan sarana kerja, kondisi atau medan kerja, alat bantu kerja, tidak sesuai dengan harapan dan kapasitas karyawan".

TPK Rejosari lebih efisien daripada TPKH Dengkol. TPK Rejosari memiliki beban kerja lebih rendah yang dikarenakan jumlah nilai beban kerja saat pemanenan lebih rendah daripada beban kerja di TPKH Dengkol. Hal ini dikarenakan banyak faktor seperti pekerja lambannya jaringan internet di TPK Karangan sehingga dalam pembuatan surat jalan maupun pemasukan data memakan waktu yang cukup lama, penempatan pegawai yang kurang tepat membuat operator TPK Karangan berlebihan beban kerjanya.

Beban Kerja Saat tidak ada pemanenan

Tabel 2. Data Penelitian Saat Tidak Ada Pemanenan

\begin{tabular}{clcllll}
\hline TPK & Kegiatan & Satuan & $\begin{array}{l}\text { Jumlah } \\
\text { volume } \\
\text { kerja }\end{array}$ & $\begin{array}{l}\text { Norma } \\
\text { waktu }\end{array}$ & $\begin{array}{l}\text { Jumlah total } \\
\text { waktu } \\
\text { kegiatan }\end{array}$ & $\begin{array}{c}\text { Total } \\
\text { Beban } \\
\text { Kerja }\end{array}$ \\
\hline \multirow{2}{*}{ Rejosari } & $\begin{array}{l}\text { Melayani penjualan } \\
\text { kayu }\end{array}$ & Waktu & 1 & 28800 detik & 28800 detik & \\
& $\begin{array}{l}\text { Menjaga kayu } \\
\text { Menjaga kayu }\end{array}$ & Waktu & 1 & 28800 detik & 28800 detik & 100800 \\
\hline
\end{tabular}




\begin{tabular}{|c|c|c|c|c|c|c|}
\hline & $\begin{array}{l}\text { (mandor } \\
\text { pengamanan) }\end{array}$ & & & & & \\
\hline \multirow{3}{*}{ Dengkol } & $\begin{array}{l}\text { Melayani penjualan } \\
\text { kayu }\end{array}$ & Waktu & 1 & 28800 detik & 28800 detik & \multirow{3}{*}{100800} \\
\hline & Menjaga kayu & Waktu & 1 & 28800 detik & 28800 detik & \\
\hline & $\begin{array}{l}\text { Menjaga kayu } \\
\text { (mandor } \\
\text { pengamanan) }\end{array}$ & Waktu & 1 & 43200 detik & 43200 detik & \\
\hline \multirow{3}{*}{ Karangan } & $\begin{array}{l}\text { Melayani penjualan } \\
\text { kayu }\end{array}$ & Waktu & 1 & 28800 detik & 28800 detik & \multirow{3}{*}{100800} \\
\hline & Menjaga kayu & Waktu & 1 & 28800 detik & 28800 detik & \\
\hline & $\begin{array}{l}\text { Menjaga kayu } \\
\text { (mandor } \\
\text { pengamanan) }\end{array}$ & Waktu & 1 & 43200 detik & 43200 detik & \\
\hline
\end{tabular}

Saat tidak ada pemanenan kayu para pegawai TPK lebih longgar kegiatannya. Para pekerja kontak jarang dipanggil oleh pihak tpk karena tidak ada kayu yang masuk, pemanggilan pekerja kontrak hanya dilakukan saat adanya penaikan kayu atau kayu yang laku. Para pegawai tetap bekerja seperti biasanya namun ridak ada kegiatan. Kurangnya kegiatan menyebabkan TPK cenderung sepi, banyak pegawai yang tidak ke tempat kerja hal ini senada dengan pendapat (Kurniawati and Mubarak 2015) "Kebosanan dalam kerja rutin sehari-hari, sebagai hasil dari terlampau sedikitnya tugas yang harus dilakukan, dapat menghasilkan berkurangnya perhatian. Untuk jangka waktu tertentu bebannya sangat ringan, untuk saat-saat lain bebannya malah berlebihan".

\section{KESIMPULAN}

Adapun kesimpulan dari peneliian tentang beban kerja ini adalah : Rata-rata beban kerja selama pemanena TPK Rejosari yaitu 237142,2 detik sedangkan rata rata beban kerja selama pemanenan TPKH Dengkol yaitu 82963,2 detik. Beban kerja saat tidak ada pemanenan di ketiga TPK sama yaitu sebesar 10800 detik. Perbedaan beban kerja saat pemanenan sangat tinggi antara TPK Rejosari dan TPKH Dengkol dipengaruhi oleh faktor internal dan faktor external seperti, faktor internal yaitu penempatan pegawai yang tidak sesuai di TPKH Dengkol sehingga membuat penyelesaian pekerjaan lama. Faktor eksternal seperti kecepatan internet yang kurang memadai di TPKH Dengkol sehingga membuat pekerjaan upload data kayu lambat setrta jumlah pekerja lepas yang berbeda membuat kegiatan penaikan kayu dan pengkaplingan kayu lama

\section{UCAPAN TERIMA KASIH}

Ucapan terima kasih kepada tuhan yang maha esa yang telah melancarkan kegiatan penelitian sehingga dapat berjalan dengan lancar. Kepada dosen pembimbing yang telah memberi arahan sehingga penelitian dan penerjaan data 
dapat terselesaikan. Kepada pegawai TPK Rejosari,TPKH Dengkol dan TPK Karangan yang telah membantu proses penelitian. Kepada kedua orang tua yang telah memberikan bantuan berupa doa sehingga peroses pengerjaan penelitian sampai pembuatan laporan dapat terselesaikan dan juga teman-teman yang telah membantu kegiatan peneliatian dan pengerjaan data

\section{DAFTAR PUSTAKA}

Aisyah, M. F., and Utami, W. (2017). Kualitas Sumber Daya Manusia, Profesionalisme Kerja , Dan Komitmen Sebagai Faktor Pendukung Peningkatan Kinerja Karyawan PDAM Kabupaten Jember (Quality of Human Resources, Labour profesionalisme , and commitment as a factor Supporting Employee Performa). $e$ jurnal Ekonomi Bisnis dan Akuntasi IV(1): 131-135.

Arif, A. (2016). Analisis yuridis pengrusakan hutan (deforestasi) dan degradasi hutan terhadap lingkungan. Jurisprudentie: Jurusan Ilmu Hukum Fakultas Syariah dan Hukum, 3(1), 33-41.

Balbeid, S. (2017). Hubungan Antara Beban Kerja Dengan Job Stress Pada Karyawan. Universitas Muhamadiyah Malang.

Hardono, I., Nasrul, H. W., \& Hartati, Y. (2019).

PENGARUH

PENEMPATAN DAN BEBAN

KERJA TERHADAP MOTIVASI

KERJA DAN DAMPAKNYA

PADA PRESTASI KERJA

PEGAWAI. JURNAL DIMENSI, 8(1), 28-43.

Juniati, S. F. (2018). Pengaruh Beban Kerja Terhadap Kinerja Karyawan Melalui Komitmen Organisasi
Sebagai Variabel Intervening Studi kasus Pada PT Sinar Sosro KPB Mojokerto. Jurusan Manajemen 6(3): 148-156.

Kementerian Lingkungan Hidup Dan Kehutanan. (2015). Peraturan Menteri Lingkungan Hidup Dan Kehutanan Republik Indonesia Nomor : P.42/Menlhk-Setjen/2015.

Keputusan Mentri Ketenagakerjaan. (2016). Pedoman Analisis Beban Kerja Di Kementrian Ketenagakerjaan. Indonesia 1-25.

Kurniawati, T., and Mubarak, A. (2015). Hubungan antara Beban Kerja dan Motivasi Kerja Pada Pegawai Departemen Alat Peralatan Kapal Laut (APKL) PT. Pindad (Persero). 355-363.

Kusuma, L. N. N. A. (2018). Perbaikan Metode Kerja Untuk Mengurangi Beban Kerja Fisik Dan Mental Operator Di CV "ED" Alumunium. Universitas Atmajaya Yogyakarta.

Octavia, K. M., Adolfina, and Lucky.O.H. (2017). Pengaruh Penempatan Kerja Dan Pengalaman Kerja Terhadap Kinerja Karyawan Pada PT.Bank Sulutgo Kantor Cabang Utama Manado. Jurnal EMBA 5(2): 2211-2220.

Qustolani, A. (2017). Pengaruh Kepuasan Kerja, Keadilan Prosedural dan Kompensasi Terhadap Kinerja karyawan. jurnal ilmiah managemen dan akutansi 4: 78-86.

Rachmat, R., Mardiyanto, R., and Budiman, F. (2015). Pengolahan Citra untuk Mengukur Diameter Terkecil Kayu guna Mengatasi Rugi akibat Kesalahan Pengukuran pada Industri Kayu. 4(2): 223-228.

Rocky, A., and Nurisani, P. N. (2018). Pengaruh Beban Kerja Teradap Kinerja Tenaga Kependidikan Pada 
Kantor Rektorat Universitas Nusa Cendana Kupang. Jourbal of Management 7(2): 225-246.

Setiawan, B. V., and Wulandari, D. R. (2016). Beban Kerja Subjektif Dan Obyektif Tenaga Farmasi Rawat Jalan Di Rumah Sakit. Jurnal Administrasi Kesehatan Indonesia 4: 28-36.

Subagja, M. G. (2015). Analisis Beban Kerja Dan Kebutuhan Karyawan Pada Divisi Produksi CV Eliman Bogor. Institut Pertanian Bogor.

Susanti. (2016). Faktor Penyebab Kelelahan dan Stres Kerja Terhadap Personel Air Traffic Controller ( ATC ) di Bandar Udara " $X$ " Air
Traffic Controller' s Fatigue and Job Stress at " X" Airport. 123-138.

Thabaran, T. (2015). Analisis beban Tenaga Kerja Filing Rekam Medis (Studi Kasus Rumah Sakit Ibu Dan Anak Bahagia Makasar). Jurnal Managemen Informasi Kesehatan Idonesia 6: 123-128.

Zulfiqar, M., Rizqiansyah, A., Hanurawan, F., and Setiyowati, N. (2017). Hubungan Antara Beban Kerja Fisik Dan Beban Kerja Mental Berbasis Ergonomi Terhadap Tingkat Kejenuhan Kerja Pada Karyawan PT Jasa Marga (PERSERO) Tbk Cabang Surabaya Gempol. 37-42. 